удк 346.9

DOI https://doi.org/10.32837/pyuv.v0i4(39).908

\author{
А. М.Селівон \\ orcid.org/0000-0002-9196-0714 \\ суддя Господарського суду м. Києва, \\ аспірант кафедри господарського права та процесу \\ Навчально-наукового інституту права \\ Управління Державної ріскальної служби України
}

\title{
ЗАСТОСУВАННЯ ЗАХОДІВ ПРОЦЕСУАЛЬНОГО ПРИМУСУ В РАЗІ НЕПОВІДОМЛЕННЯ СУДУ ПРО НЕМОЖЛИВІСТЬ ПОДАТИ ДОКАЗИ, ВИТРЕБУВАНІ СУДОМ, АБО НЕПОДАННЯ ТАКИХ ДОКАЗІВ БЕЗ ПОВАЖНИХ ПРИЧИН
}

Постановка проблеми. Швидкому та об'єктивному розгляду справ сприяє належне дотримання учасниками господарського процесу, а також особами, присутніми в залі судового засідання, їхніх обов'язків, передбачених господарським процесуальним законодавством. Заходи процесуального примусу застосовуються судом до осіб, які порушують встановлені в суді правила і перешкоджають здійсненню господарського судочинства. Під порушенням встановлених у суді правил розуміється невиконання процесуальних обов'язків, передбачених Господарським процесуальним кодексом України (далі - ГПК України) і (або) покладених судом на певну особу, відповідно до положень Кодексу (наприклад, обов'язків сумлінно використовувати процесуальні права, з'явитися на судове засідання, надавати докази). Вперше інститут заходів процесуального примусу був закріплений в окремому розділі ГПК України лише в чинній його редакції.

Аналіз останніх дослідженьі іпубікацій. Проблемами процесуального примусу та господарсько-процесуальної відповідальності займалися В. Бобрик, О. Бондаренко, В. Григорьєва, Н. Іванюта, А. Катрич, О. Кікоть, А. Коліна, К. Куцик, Л. Медведюк, А. Первушина, О. Перекрестная, О. Подцерковний, В. Рєзнікова, О. Рожнов, В. Чернега.

$\mathrm{У}$ науці господарського процесуального права ще не досить досліджена сфера процесуального примусу, чітко не вироблені рекомендації щодо застосування відповідних заходів, зокрема заходів процесуального примусу в разі вчинення деяких господарсько-процесуальних порушень.

Мета статті. На основі вивчених досліджень та публікацій було поставлено завдання - проаналізувати ті заходи процесуального примусу, які застосовуються в разі неповідомлення суду про неможливість подати докази, витребувані судом, або неподання таких доказів без поважних причин у господарському процесі.

Виклад основного матеріалу дослідження. Господарський процесуальний кодекс передбачає розгорнуту систему заходів відповідальності, а також інших заходів процесуального примусу, які не є безпосередньо заходами відповідальності.
Традиційно у процесуальній науці вважається, що санкції - це встановлені в нормах процесуального права наслідки, які настають за недодержання та порушення цих норм. Їх поділяють на заходи захисту (наприклад, відмова у прийнятті заяви до провадження суду, залишення заяви без руху, попередження) і заходи відповідальності (стягнення судових витрат і збитків, примусовий привід, видалення з залу судового засідання тощо) [1, с. 16].

С. Афанасьєв вважає, що примусові заходи в арбітражному процесі не вичерпуються лише заходами процесуальної відповідальності - існує велика кількість заходів, які не можна віднести до заходів відповідальності, незважаючи на їхній примусовий характер. У теорії права для позначення примусових заходів, які не мають характеру відповідальності, використовується термін «заходи захисту».

Їх відокремлення від заходів відповідальності будується, по-перше, на підставі застосування (заходи відповідальності настають за правопорушення в разі наявності вини, а заходи захисту можуть застосовуватися незалежно від провини і складу правопорушення); по-друге, за функціональним призначенням (заходи захисту спрямовані на забезпечення недоторканності прав і ліквідацію наслідків порушення, а заходи відповідальності на покарання винних та попередження правопорушень) [2, с. 228].

Владний характер процесуальних відносин надає багатьом процесуальним діям, що здійснюються господарським судом, примусовості, у зв'язку 3 чим межа між діями, функціонально орієнтованими на захист від правопорушень, та іншими діями певним чином стирається.

О. Світличний визначає заходи процесуального примусу як процесуальні дії, що вчиняються судом за наявності підстав та у випадках, передбачених господарсько-процесуальним законом, із метою спонукання відповідних осіб до виконання встановлених прав і процесуальних обов'язків [3, с. 143]. В. Бобрик процесуальним примусом називає фізичний або моральний (психологічний) вплив держави в особі суду на суб'єктів судового процесу (учасників процесу й інших осіб, присутніх у залі судового 
засідання) з метою забезпечення їх належної поведінки під час розгляду справи, який у вигляді встановлених законом правообмежень здійснюється безпосередньо судом або за його дорученням іншими уповноваженими органами державної влади під час розгляду цивільної справи у випадках, коли авторитету закону та суду, а також переконання в необхідності виконання нормативних приписів недостатньо [2, с. 17].

В. Чернега пропонує вважати заходами процесуального примусу закріплені в нормах господарського процесуального права процесуальні дії, що вчиняються судом у спеціально встановленому порядку в разі невиконання учасниками судового процесу та іншими присутніми у судовому засіданні встановлених у суді правил, недобросовісного виконання процесуальних обов'язків, зловживання процесуальними правами, протиправного перешкоджання у здійсненні господарського судочинства [4, с. 183].

О. Рожнов зазначає, що правовий примус складне за своєю структурою явище, яке об'єднує заходи юридичної відповідальності та заходи захисту (відновлення) правопорядку. Юридична відповідальність полягає у застосуванні заходів правового примусу до правопорушників із метою покарання особи, яка вчинила правопорушення. Заходи захисту (відновлення) правопорядку - це різновид правового примусу, який застосовується для поновлення нормального стану правовідносин за допомогою спонукання суб'єктів права до виконання тих чи інших обов'язків. Виходячи 3 цього, юридична відповідальність від заходів захисту відрізняється: а) спрямованістю (відповідальність спрямована передусім на порушника, а захист права - більше на уповноваженого); б) підставами застосування - відповідальність настає лише за наявності правопорушення (винне, осудне діяння, яке завдає шкоду суспільству), натомість захист права допускається і в силу об'єктивно протиправного діяння, а в деяких випадках - i за відсутності протиправності; в) функціями (функція юридичної відповідальності - штрафна, карна; функція ж заходів захисту зводиться до забезпечення виконання юридичного обов'язку); г) способами впливу на поведінку суб'єктів права (відповідальність завжди передбачає морально-психологічне перетворення особи та пов'язана з осудом правопорушника, зі спричиненням певних позбавлень [5, с. 188].

Відповідно до ст. 131 ГПК України заходами процесуального примусу є процесуальні дії, що вчиняються судом у визначених випадках із метою спонукання відповідних осіб до виконання встановлених у суді правил, добросовісного виконання процесуальних обов'язків, припинення зловживання правами та запобігання створенню протиправних перешкод у здійсненні судочин- ства. Заходи процесуального примусу застосовуються судом за допомогою постановлення ухвали [6].

Виокремлюють формальну та фактичну підстави настання господарсько-процесуальної відповідальності. Формальною підставою є норми господарського процесуального права, в диспозиціях яких сформульовані обов'язки, а в санкціях - заходи відповідальності. Фактичною підставою визнається процесуальне правопорушення, тобто порушення приписів процесуального законодавства у вигляді невиконання учасником господарського процесу своїх процесуальних обов'язків або порушення процесуальних заборон [7, с. 53].

Процесуальне правопорушення $\epsilon$ порушенням вимог господарсько-процесуальної норми, вчиненим конкретною особою - суб'єктом господарських процесуальних відносин, у вигляді свідомого невиконання відповідних процесуально-правових обов'язків.

В основі процесуального правопорушення лежить порушення вимог процесуального закону. Однак не кожна суперечність приписам норм права може вважатися протиправною; основною ознакою протиправності є невиконання юридичного обов'язку. У процесуальному праві протиправність може утворюватися в разі невиконання або неналежного виконання особою процесуального обов'язку.

Розглядаючи у статті застосування заходів процесуального примусу за неповідомлення суду про неможливість подати докази, витребувані судом, або неподання таких доказів без поважних причин, можна зробити висновок, що підставами для застосування відповідальності можуть стати такі види порушень господарського процесуального законодавства:

- неповідомлення суду про неможливість подати докази, витребувані судом;

- неподання доказів, витребуваних судом, без поважних причин.

Згідно зі ст. 74 ГПК України кожна сторона повинна довести ті обставини, на котрі вона посилається як на підставу своїх вимог або заперечень.

У разі посилання учасника справи на невчинення іншим учасником справи певних дій або відсутність певної події суд може зобов'язати такого іншого учасника справи надати відповідні докази вчинення цих дій або наявності певної подіï. В разі ненадання таких доказів суд може визнати обставину невчинення відповідних дій або відсутності події встановленою.

Докази подаються сторонами та іншими учасниками справи.

Суд не може збирати докази, що стосуються предмета спору, з власної ініціативи, крім витребування доказів судом у випадку, коли він має сумніви в добросовісному здійсненні учасниками справи своїх процесуальних прав або у виконанні обов'язків щодо доказів. 
Головна проблема полягає в тому, що незрозуміло, в яких саме випадках можна стверджувати, що учасники справи недобросовісно виконують свої обов'язки щодо доказування. Категорія «добросовісність» нормативно не визначена, отже, це питання вирішується за допомогою дискреційних повноважень суду, на підставі його внутрішнього переконання. Тому можливими є зловживання 3 боку суду з метою витребування доказів із власної ініціативи, що в такому разі однозначно призводить до порушення принципу змагальності цивільного судочинства. А порушення основної засади можна трактувати як порушення процесуального закону. Докази, витребувані судом за таких обставин, можна розглядати як недопустимі, адже вони одержані з порушенням порядку, визначеного ГПК України. Використання судом таких доказів під час ухвалення судового рішення може призвести до ухвалення незаконного та/ або необгрунтованого судового рішення. В разі доведення зв'язку між незаконним витребуванням доказів судом із власної ініціативи й ухваленням незаконного та/або необгрунтованого судового рішення на це можна посилатись як на підставу для скасування судового рішення (незаконність), що базується на витребуваних таким чином доказах в апеляційному порядку [8].

Таким чином, відповідно до положень ГПК України обов'язок доказування покладається на сторони та інших учасників справи, а у випадках, визначених ГПК України, право збирати докази за власною ініціативою має суд.

Згідно з положеннями ст. 81 ГПК України учасник справи в разі неможливості самостійно надати докази має право подати клопотання про витребування доказів судом.

У разі задоволення клопотання суд своєю ухвалою витребуватиме відповідні докази.

Суд може витребувати докази також до подання позову як захід забезпечення доказів.

Суд може уповноважити на одержання витребуваних ним доказів зацікавлену сторону.

Будь-яка особа, в якої знаходиться доказ, повинна видати його на вимогу суду.

Особи, які не мають можливості подати доказ, що витребовує суд, або не мають можливості подати такий доказ у встановлені строки, зобов'язані повідомити про це суд із зазначенням причин упродовж п'яти днів із дня вручення ухвали.

У разі неповідомлення суду про неможливість подати докази, витребувані судом, або неподання таких доказів без поважних причин суд застосовує до відповідної особи заходи процесуального примусу, передбачені ГПК України.

$\mathrm{У}$ разі неподання учасником справи витребуваних судом доказів без поважних причин або без повідомлення причин суд, залежно від того, яка особа ухиляється від їх подання та яке значення мають ці докази, може визнати обставину, для з'ясування якої витребовувався доказ, або відмовити в її визнанні, або розглянути справу за наявними в ній доказами, а у разі неподання таких доказів позивачем - також залишити позовну заяву без розгляду.

3 огляду на вищезазначене доходимо висновку, що в разі неподання доказів, що витребувані судом відповідною ухвалою про витребування або забезпечення доказів, без поважних причин або без повідомлення причин їх неподання, залежно від того, яка особа ухиляється від їх подання та яке значення мають ці докази, суд може:

- застосувати до відповідної особи заходи процесуального примусу;

- визнати обставину, для з'ясування якої витребовувався доказ;

- відмовити у визнанні обставини, для з'ясування якої витребовувався доказ;

- розглянути справу за наявними в ній доказами;

- залишити позовну заяву без розгляду в разі неподання витребуваних доказів позивачем.

У разі неповідомлення суду про неможливість подати докази, витребувані судом, або неподання таких доказів без поважних причин суд застосовує до відповідної особи заходи процесуального примусу, передбачені ГПК України [6].

Із передбачених ст. 131 ГПК України видів заходів процесуального примусу за неповідомлення суду про неможливість подати докази, витребувані судом, або неподання таких доказів без поважних причин можуть застосовуватися такі заходи, як тимчасове вилучення доказів для дослідження судом і штраф.

Ч. 1 ст. 134 ГПК України встановлено, що в разі неподання письмових, речових чи електронних доказів, що витребувані судом, без поважних причин або без повідомлення причин суд може постановити ухвалу про тимчасове вилучення цих доказів державним виконавцем для дослідження судом.

Відповідно до п. 3 ч. 1 ст. 135 ГПК України суд може постановити ухвалу про стягнення в дохід державного бюджету з відповідної особи штрафу в сумі від одного до десяти розмірів прожиткового мінімуму для працездатних осіб у випадках неповідомлення суду про неможливість подати докази, витребувані судом, або неподання таких доказів без поважних причин [6].

С. Пилипенко, вивчаючи тимчасове вилучення доказів для дослідження судом у цивільному процесі, доходить висновку, що тимчасове вилучення доказів для дослідження судом не є видом юридичної відповідальності та може бути поєднане зі стягненням штрафу в дохід держави за неподання доказів, що витребувані судом, без поважних причин або без повідомлення причин їх неподання [9, с. 90].

О. Рожнов вважає тимчасове вилучення доказів для дослідження судом превентивним 
процесуальним заходом оперативного реагування суду на дії, які протиправно перешкоджають здійсненню цивільного судочинства. Цей захід процесуального примусу спрямований на припинення наявного протиправного діяння у вигляді неподання без поважних причин письмових чи речових доказів, що витребувані судом, та неповідомлення причин їх неподання [5, с. 189].

Тимчасове вилучення доказів для дослідження судом - це превентивний процесуальний захід оперативного реагування суду на дії, які протиправно перешкоджають здійсненню господарського судочинства. Він спрямований на припинення наявного протиправного діяння у вигляді неподання без поважних причин письмових, речових чи електронних доказів, що витребувані судом, та неповідомлення причин їх неподання. Обов’ язкова умова його застосування - наявність ухвали суду про витребування письмових, речових чи електронних доказів, яка має характер владного правозастосовного акта, на підставі якого виникає правовідношення, де праву суду витребувати доказ кореспондує обов'язок особи надати суду витребуваний доказ або повідомити причини його неподання [10, с. 106].

В ухвалі про тимчасове вилучення доказів для дослідження судом зазначаються:

1) повне найменування (для юридичних осіб) або ім'я (прізвище, ім'я та по батькові для фізичних осіб) особи, в якої знаходиться доказ, їі місцезнаходження (для юридичних осіб) або місце проживання чи перебування (для фізичних осіб), поштові індекси, ідентифікаційний код юридичної особи в Єдиному державному реєстрі підприємств і організацій України, номери засобів зв'язку та адреса електронної пошти за наявності;

2) назва або опис письмового, речового чи електронного доказу;

3) підстави проведення тимчасового вилучення доказу;

4) кому доручається вилучення.

Ухвала про тимчасове вилучення доказів для дослідження судом є виконавчим документом, підлягає негайному виконанню та має відповідати вимогам до виконавчого документа, встановленим законом. Стягувачем за таким виконавчим документом є Державна судова адміністрація України.

Ухвала про тимчасове вилучення доказів для дослідження судом не оскаржується.

Виконання ухвали про тимчасове вилучення доказів для дослідження судом покладається виключно на органи державної виконавчої служби, адже саме ці органи, відповідно до чинного законодавства України, уповноважені виконувати судові рішення та наділені повноваженнями щодо застосування заходів державного примусу.

В. Рєзнікова вважає, що тимчасове вилучення доказів для дослідження судом прямо суперечить принципам змагальності, рівності сторін у процесі, диспозитивності та з'ясування всіх обставин справи. Уможливлюється таким чином (санкціонується) і втручання суду в право власності, адже доказами можуть бути предмети матеріального світу, які своїм існуванням, якостями, властивостями, місцезнаходженням, іншими ознаками дають змогу встановити обставини, що мають значення для справи.

Слід звернути увагу, що ГПК України не врегульовано, чи зазначаються в ухвалі про тимчасове вилучення доказів місце зберігання тимчасово вилучених доказів, особи, на яких покладається відповідальність за їх збереження (державний виконавець чи суд), а також порядок повернення їх власнику. Також вважається необхідним передбачити повернення речових доказів та оригіналів письмових й електронних доказів особі, в якої вони були вилучені, без її клопотання.

Найбільш суворим заходом процесуального примусу в господарському процесі є штраф. Згідно зі ст. 135 ГПК України суд може постановити ухвалу про стягнення в дохід державного бюджету з відповідної особи штрафу в сумі від одного до десяти розмірів прожиткового мінімуму для працездатних осіб у разі:

1) невиконання процесуальних обов'язків, зокрема ухилення від вчинення дій, покладених судом на учасника судового процесу;

2) зловживання процесуальними правами, вчинення дій або допущення бездіяльності з метою перешкоджання судочинству;

3) неповідомлення суду про неможливість подати докази, витребувані судом, або неподання таких доказів без поважних причин;

4) невиконання ухвали про забезпечення позову або доказів, ненадання копії відзиву на позов, апеляційну чи касаційну скаргу, відповіді на відзив, заперечення іншому учаснику справи у встановлений судом строк;

5) порушення заборон, встановлених ч. 10 ст. 188 ГПК України.

У разі повторного чи систематичного невиконання процесуальних обов'язків, повторного чи неодноразового зловживання процесуальними правами, повторного чи систематичного неподання витребуваних судом доказів без поважних причин або без їх повідомлення, тривалого невиконання ухвали про забезпечення позову або доказів суд із урахуванням конкретних обставин стягує в дохід державного бюджету з відповідного учасника судового процесу або відповідної іншої особи штраф у сумі від п'яти до п'ятдесяти розмірів прожиткового мінімуму для працездатних осіб.

У разі невиконання процесуальних обов'язків, зловживання процесуальними правами представником учасника справи суд із урахуванням конкретних обставин справи може стягнути штраф як з учасника справи, так і з його представника. 
Ухвала про стягнення штрафу, на відміну від ухвали про тимчасове вилучення доказів для дослідження судом, може бути оскаржена в апеляційному порядку до суду вищої інстанції, крім ухвали Верховного Суду про стягнення штрафу, яка оскарженню не підлягає. Постанова суду апеляційної інстанції за результатами перегляду ухвали про накладення штрафу є остаточною й оскарженню також не підлягає.

Ухвала про стягнення штрафу є виконавчим документом та має відповідати вимогам до виконавчого документа, встановленим законом. Стягувачем за таким виконавчим документом є Державна судова адміністрація України.

Якщо особа, стосовно якої винесено ухвалу, виправила допущене порушення та (або) надала докази поважності причин невиконання відповідних вимог суду чи своїх процесуальних обов'язків, суд може скасувати постановлену ним ухвалу про стягнення штрафру.

А. Коліна зазначає, що штрафні санкції є формою господарської процесуальної відповідальності, яка застосовується виключно у випадках, встановлених законом, та чітко спрямована на виконання приписів господарського процесуального законодавства. Штрафні санкції - це специфічні санкції, що мають комплексний, самостійний та виключно грошовий характер [11, с. 432].

В. Рєзнікова та М. Курей визначають штраф як форму господарської процесуальної відповідальності, що полягає в накладенні господарським судом грошового стягнення у дохід держави на особу, що вчинила господарське процесуальне правопорушення, передбачене ч. 1 ст. 135 ГПК України, через постановлення відповідної ухвали з метою спонукання учасників процесу до добросовісного користування процесуальними правами, а також до сумлінного виконання своїх процесуальних обов'язків [12, с. 95].

Висновки. На підставі проведеного дослідження можна зробити висновок, що чинна редакція ГПК України є більш прогресивною з погляду систематизації засобів впливу на учасників процесу, які недобросовісно виконують процесуальні обов'язки, зловживають правами та перешкоджають здійсненню судочинства. В разі неповідомлення суду про неможливість подати докази, витребувані судом, або неподання таких доказів без поважних причин суд застосовує до відповідної особи заходи процесуального примусу, передбачені ГПК України. Це може бути тимчасове вилучення доказів та/або штраф. Тимчасове вилучення доказів для дослідження судом не є видом юридичної відповідальності та може бути поєднане зі стягненням штрафу в дохід держави. Тимчасове вилучення доказів - це превентивний процесуальний захід оперативного реагування суду на дії, які протиправно перешкоджають здійсненню господарського судочинства, тоді як стягнення штрафу є формою господарської процесуальної відповідальності.

\section{Jimepamypa}

1. Бобрик В. Заходи процесуального примусу: порівняльно-правовий аналіз у різних видах цивілістичного судочинства. Підприємництво, господарство і право. 2014. № 10(226). С. 16-22.

2. Арбитражное процессуальное право в 2 ч. Часть 1 : учебник для бакалавриата и магистратуры / С. Афанасьев и др. ; под ред. С. Афанасьева, И. Захарьящевой. Москва : Юрайт, 2019. 399 с.

3. Світличний О. Господарський процес : підручник. Вид. друге, перероб. і доп. Київ : НУБіП України, 2018. $342 \mathrm{c}$.

4. Чернега В. Заходи процесуального примусу в господарському процесуальному праві. Правове регулювання економіки. 2018. № 17. С. 180-189.

5 . Рожнов 0. Тимчасове вилучення доказів для дослідження судом. Вісник Харківського національного університету ім. В.Н. Каразіна. Серія «Право». 2013. Вип. 16. С. 187-191.

6. Господарський процесуальний кодекс України : Закон України від 6 листопада 1991 р. № 1798-XII (редакція від 5 грудня 2017 p.). URL: http://zakon.rada.gov.ua/ laws/show/1798-12 (дата звернення: 07.10.2021).

7. Катрич А. Позитивна відповідальність у господарсько-процесуальному праві. Піәприємництво, господарство і право. 2017. № 5. С. 51-54.

8. Гулевська Д. Проблема витребування доказів судом із власної ініціативи у цивільному судочинстві. Платформа Укрголос : вебсайт. URL: https://www.ukrlogos.in.ua/10.11232-2663-4139.07.08. html (дата звернення: 07.10.2021).

9. Пилипенко С. Особливості тимчасового вилучення доказів для дослідження судом. Jurnalyl Juridic National: Teorie si practica. 2019. № 5. C. 88-92.

10. Рєзнікова В. Відповідальність у господарському процесі за зловживання процесуальними правами та заходи процесуального примусу. Право України. 2017. № 9. C. 102-121.

11. Коліна А. Штрафні санкції в господарському процесі. Актуальні проблеми держави і права : збірник наукових праць. Вип. 66. Одеса : Юридична літератуpa, 2012. C. 427-433.

12. Рєзнікова В., Курей М. Штраф як форма господарсько-процесуальної відповідальності. Право України. 2020. № 7. С. 78-97.

\section{Анотація}

Селівон А. М. Застосування заходів процесуального примусу в разі неповідомлення суду про неможливість подати докази, витребувані судом, або неподання таких доказів без поважних причин. - Стаття.

У статті розглянуто проблематику застосування заходів процесуального примусу в разі неповідомлення суду про неможливість подати докази, витребувані судом, або неподання таких доказів без поважних причин у господарському процесі.

Швидкому та об'єктивному розгляду справ сприяє належне дотримання учасниками господарського процесу, а також особами, присутніми в залі судового засідання, їхніх обов'язків, передбачених господарським процесуальним законодавством. Заходи процесуального примусу застосовуються судом до осіб, які порушують встановлені в суді правила і перешкоджають 
здійсненню господарського судочинства. Під порушенням встановлених у суді правил розуміється невиконання процесуальних обов'язків, передбачених ГПК України і (або) покладених судом на певну особу, відповідно до положень Кодексу (наприклад, обов'язків сумлінно використовувати процесуальні права, з'явитися на судове засідання, надавати докази). Вперше інститут заходів процесуального примусу був закріплений в окремому розділі Господарського процесуального кодексу України лише у чинній його редакції.

Господарський процесуальний кодекс передбачає розгорнуту систему заходів відповідальності, а також інших заходів процесуального примусу, які не є безпосередньо заходами відповідальності.

Традиційно в процесуальній науці вважається, що санкції - це встановлені в нормах процесуального права наслідки, які настають за недодержання та порушення цих норм. Їх поділяють на заходи захисту (наприклад, відмова у прийнятті заяви до провадження суду, залишення заяви без руху, попередження) і заходи відповідальності (стягнення судових витрат і збитків, примусовий привід, видалення з залу судового засідання тощо).

Чинна редакція ГПК України є більш прогресивною з погляду систематизації засобів впливу на учасників процесу, які недобросовісно виконують процесуальні обов'язки, зловживають правами та перешкоджають здійсненню судочинства. В разі неповідомлення суду про неможливість подати докази, витребувані судом, або неподання таких доказів без поважних причин суд застосовує до відповідної особи заходи процесуального примусу, передбачені ГПК України. Це може бути тимчасове вилучення доказів та/або штраф. Тимчасове вилучення доказів для дослідження судом не є видом юридичної відповідальності та може бути поєднане зі стягненням штрафу в дохід держави. Тимчасове вилучення доказів $€$ превентивним процесуальним заходом оперативного реагування суду на дії, які протиправно перешкоджають здійсненню господарського судочинства, тоді як стягнення штрафу є формою господарської процесуальної відповідальності.

Ключові слова: господарський процес, господарсько-процесуальна відповідальність, заходи процесуального примусу, господарське процесуальне правопорушення, докази, витребування доказів, штраф, тимчасове вилучення доказів.

\section{Summary}

Selivon $A$. M. The use of coercive measures in case of failure to notify the court about inability to present evidence requested by the court or failure to present such evidence without valid reasons. - Article.

The article considers the problematics of the use of coercive measures in case of failure to notify the court of the impossibility to submit evidence required by the court, or failure to provide such evidence without good reason in the commercial process.

Prompt and objective consideration of cases is facilitated by the proper observance by participants in the economic process, as well as persons present in the courtroom of their duties stipulated by the economic procedural legislation. Measures of procedural coercion shall be applied by the court to persons who violate the rules established by the court and hinder the implementation of economic legal proceedings. Thus, violation of the rules established by the court means nonfulfillment of procedural obligations stipulated by the Economic Procedural Code of Ukraine and (or) imposed by the court on a certain person in accordance with the provisions of the Code (for example, obligations to use procedural rights in good faith, to appear in court, to provide evidence). For the first time the institute of procedural coercive measures was enshrined in a separate section of the Commercial Procedural Code of Ukraine only in its current version.

The Commercial Procedural Code of Ukraine provides for a detailed system of sanctions, as well as other measures of procedural coercion, which are not sanctions in their pure form.

Traditionally, procedural science considers that sanctions are consequences established in the rules of procedural law, which occur for non-compliance and violation. They are divided into protective measures (e.g., refusal to accept an application for proceedings, leaving an application without progress, a warning) and liability measures (recovery of court costs and damages, compulsory process, removal from the courtroom, etc.).

The current version of the Commercial Procedural Code of Ukraine is more progressive in terms of systematization of means of influence on participants of the process who dishonestly perform procedural obligations, abuse their rights and interfere in the proceedings. In case of failure to notify the court on the impossibility to submit the evidence requested by the court or failure to submit such evidence without a valid reason, the court applies measures of procedural coercion to the respective person as provided by the Civil Procedure Code of Ukraine. This may be temporary seizure of evidence and/or a fine. Temporary seizure of evidence for examination by the court is not a type of legal liability and can be combined with a fine to the benefit of the state. Temporary seizure of evidence is a preventive procedural measure of prompt response of the court to actions that unlawfully interfere with economic proceedings, while the imposition of a fine is a form of economic procedural liability.

Key words: economic process, economic procedural responsibility, measures of procedural coercion, economic procedural offence, evidence, reclamation of evidence, fine, temporary seizure of evidence. 